\title{
Greig Cephalopolysyndactyly Contiguous Gene Syndrome: Case Report and Literature Review
}

\author{
Kinga Kozma 1,2,3,*, Marius Bembea 1,2,3 , Claudia M. Jurca 1,2,3, Mihai Ioana 4,5, Ioana Streață 4,5, \\ Simona Ş. Şoşoi ${ }^{4,5}$, Andrei Pirvu ${ }^{4,5}$, Codruța D. Petchesi 1,*(D), Ariana Szilágyi 1,3, Cristian N. Sava 1,3(1),
} Alexandru Jurca ${ }^{1}$, Anikó Ujfalusi ${ }^{6}$, Zsuzsanna Szúcs ${ }^{6}{ }^{6}$ and Katalin Szakszon ${ }^{7}$

1 Faculty of Medicine and Pharmacy, University of Oradea, 410073 Oradea, Romania; bembea13@yahoo.com (M.B.); claudiajurca70@yahoo.com (C.M.J.); szilagyi.ariana@gmail.com (A.S.); cristian.sava2004@gmail.com (C.N.S.); alexjurca@yahoo.co.uk (A.J.)

2 Regional Center of Medical Genetics Bihor, 410445 Oradea, Romania

3 Municipal Clinical Hospital “Dr. Gavril Curteanu”, 410469 Oradea, Romania

4 Regional Center of Medical Genetics Dolj, 200349 Craiova, Romania; mihai.ioana@umfcv.ro (M.I.); ioana.streata@yahoo.com (I.S.); simona.sosoi@umfcv.ro (S.S..Ş.); andrei.pirvu9@gmail.com (A.P.)

5 Human Genomics Laboratory, Faculty of Medicine, University of Medicine and Pharmacy Craiova, 200642 Craiova, Romania

6 Division of Clinical Genetics, Faculty of Medicine, Departament of Laboratory Medicine, University of Debrecen, 4032 Debrecen, Hungary; ujfalusi.aniko@med.unideb.hu (A.U.); szucs.zsuzsanna@med.unideb.hu (Z.S.)

7 Faculty of Medicine, Departament of Pediatrics, University of Debrecen, 4032 Debrecen, Hungary; szakszon.katalin@gmail.com

check for updates

Citation: Kozma, K.; Bembea, M.; Jurca, C.M.; Ioana, M.; Streață, I.; Şoşoi, S.Ş.; Pirvu, A.; Petchesi, C.D.; Szilágyi, A.; Sava, C.N.; et al. Greig Cephalopolysyndactyly Contiguous Gene Syndrome: Case Report and Literature Review. Genes 2021, 12, 1674. https://doi.org/10.3390/ genes12111674

Academic Editor: William Newman

Received: 18 September 2021

Accepted: 21 October 2021

Published: 23 October 2021

Publisher's Note: MDPI stays neutral with regard to jurisdictional claims in published maps and institutional affiliations.

Copyright: (c) 2021 by the authors. Licensee MDPI, Basel, Switzerland. This article is an open access article distributed under the terms and conditions of the Creative Commons Attribution (CC BY) license (https:// creativecommons.org/licenses/by/ $4.0 /)$.
* Correspondence: kkozma@uoradea.ro (K.K.); petchesi_diana@yahoo.com (C.D.P.); Tel.: +40-744-708-777 (K.K.)

\begin{abstract}
Greig cephalopolysyndactyly syndrome (GCPS) is a rare genetic disorder (about 200 cases reported), characterized by macrocephaly, hypertelorism, and polysyndactyly. Most of the reported GCPS cases are the results of heterozygous loss of function mutations affecting the GLI3 gene (OMIM\# 175700), while a small proportion of cases arise from large deletions on chromosome 7p14 encompassing the GLI3 gene. To our knowledge, only 6 patients have been reported to have a deletion with an exact size (given by genomic coordinates) and a gene content larger than $1 \mathrm{Mb}$ involving the GLI3 gene. This report presents a patient with Greig cephalopolysyndactyly contiguous gene syndrome (GCP-CGS) diagnosed with a large, $18 \mathrm{Mb}$ deletion on chromosome 7p14.2-p11.2. Similar cases are reviewed in the literature for a more accurate comparison between genotype and phenotype.
\end{abstract}

Keywords: Greig cephalopolysyndactyly; Greig cephalopolysyndactyly contiguous gene syndrome; array-CGH; structural chromosomal anomalies; deletion 7p

\section{Introduction}

Greig cephalopolysyndactyly syndrome (GCPS) is a rare genetic disorder ( 200 cases reported), characterized by macrocephaly, hypertelorism, polysyndactyly and most commonly normal intelligence [1-4].

Both small-scale (missense, nonsense, splicing variants, small deletions, small insertions, and indels) and large-scale alterations (gross deletions, gross insertions, and translocations) affecting the GLI3 gene $(\sim 300 \mathrm{~kb})$, located on chromosome 7p14.1 can cause GCPS (MIM\# 175700) [5] in an autosomal dominant mode of inheritance [1,2,6-8].

Cases with a chromosomal microdeletion encompassing GLI3 (deletions larger than $1 \mathrm{Mb}$ ) are referred to as GPS-CGS, and they typically present with a more complex neurobehavioral phenotype including intellectual disability, severe motor retardation and neurological symptoms [2,6]. 
In this study, we describe a child of non-consanguineous parents with severe developmental disability diagnosed with a large interstitial deletion of chromosome $7 p$, using array comparative genomic hybridization. The molecular karyotype revealed a deletion of $18 \mathrm{Mb}$ on chromosome 7p14.2-p11.2, which is the largest chromosomal deletion described in the related literature so far [1-19].

\section{Materials and Methods}

\subsection{Patient}

A 3-year-old boy was referred to our Genetics Department of Municipal Clinical Hospital "Dr. Gavril Curteanu" Oradea, Romania, due to psychomotor developmental delay and multiple congenital anomalies. He is the second child of healthy and unrelated parents, whose first child is a healthy girl.

The patient was born from an uneventful pregnancy as the second child of the parents, in the 34th week, via vaginal delivery. Macrosomia (the birth weight was $3030 \mathrm{~g}$, 97th percentile and length $48 \mathrm{~cm}$, 90th percentile), macrocephaly (OFC was $36 \mathrm{~cm}, 1 \mathrm{~cm}>97 \mathrm{th}$ percentile), and congenital malformations of the face and limbs were noted at birth. Perinatal hypoxia was suspected based on the Apgar scores (5/1,7/5, and 8/10).

\subsection{Neuroimaging}

Cranial ultrasound at birth and magnetic resonance imaging (MRI) was performed at 1 year and at 3 years.

\subsection{Classical and Molecular Cytogenetic Investigations}

An informed consent was obtained from the patient's parents as legal representatives, to collect blood, take pictures, and access medical data.

Karyotyping was performed at the Clinical Genetics Center of the University of Debrecen, Hungary, from peripheral blood using the G-banding technique, with 500 bands, 15 metaphases were analyzed. Image analysis was done using CytoVision Software.

Molecular cytogenetic analyses were performed at the Regional Center of Medical Genetics Dolj (Romania). Genomic DNA was extracted from peripheral venous blood using Wizard ${ }^{\circledR}$ Genomic DNA Purification Kit (Promega, Madison, WI, USA), following the manufacturer's protocol. DNA concentration and quality were measured using a spectrophotometer (Eppendorf Biophotometer). A total of $0.5 \mu \mathrm{g}$ of genomic DNA was used for array comparative genomic hybridization $(\mathrm{aCGH})$ analysis following the manufacturer's protocol. It was performed using a microarray slide with 120,000 oligonucleotide and 60,000 SNP probes (180K) covering the entire human genome with an average spatial resolution of 25 kb DNA (G4890A, ID design: 029830_20100921, Genom hg38 build; Agilent). The post-hybridization data were obtained using the Feature Extraction programme, and their subsequent analysis was performed with the CytoGenomics programme, Agilent.

\section{Results}

\subsection{Morphological Evaluation of the Patient}

When he was one year old, macrocephaly (OFC: $48.5 \mathrm{~cm}$, 95th percentile) was observed (Figure 1a) and at the age of three, macro-acrocephaly (OFC: $53 \mathrm{~cm}, 1 \mathrm{~cm}>95$ th percentile) was seen (Figure 1b,c). Observations included prominent metopic suture and high anterior hairline with right frontal upsweep; sparse eyebrows, hypertelorism, upslanted telecanthus, and palpebral fissures; convergent strabism; depressed and wide nasal bridge, anteverted nares, broad nasal base, and broad and high inserted columella; deep naso-labial creases; long and broad philtrum, and thick upper lip; microdontia; pointed chin with a horizontal deep crease; pigmented nevus on the right cheek (Figure 1a-c); low inserted ears with out-sticking upper one-third, and a pit on the crus of the helix (Figure 1c,d). 


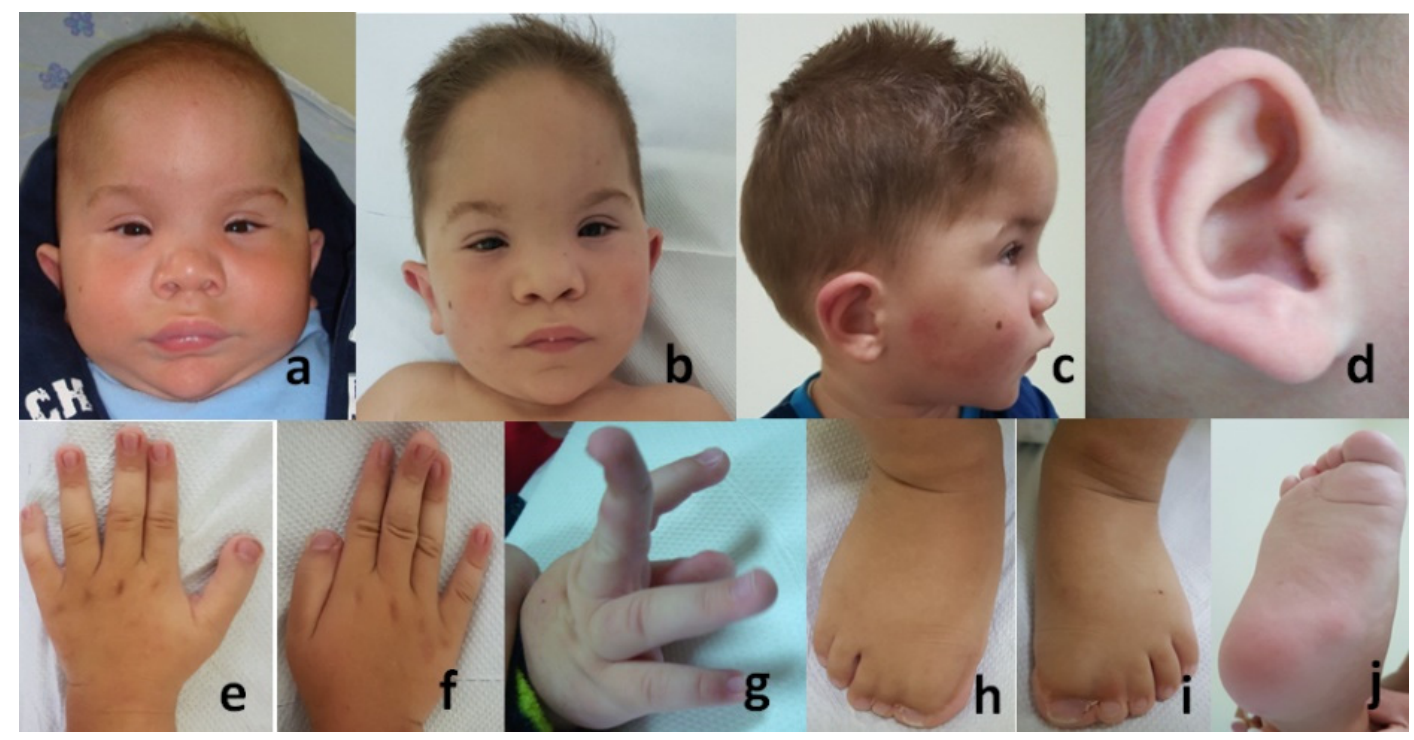

Figure 1. (a-d) shows cranio-facial features of the patient: macrocephaly at the age of 1 year (a), and macro-acrocephaly at 3 years $(\mathbf{b}, \mathbf{c})$; prominent high anterior hairline with right frontal upsweep; sparse eyebrows, hypertelorism, telecanthus, and upslanted palpebral fissures; convergent strabism; depressed and wide nasal bridge, anteverted nares, and broad nasal base with broad and high inserted columella; long and broad philtrum, and deep naso-labial fold; thick upper lip; pointed chin with a horizontal deep crease; pigmented nevus on the right cheek $(\mathbf{a}-\mathbf{c})$; low inserted ears with out-sticking upper one-third of the pinnae, and a pit on the crus of the helix $(\mathbf{c}, \mathbf{d}) .(\mathbf{e}-\mathbf{j})$ Digital anomalies of the hands and feet: squared broad thumbs $(\mathbf{e}, \mathbf{f})$; joint laxity with dorsiflexion of the distal phalanges $(\mathbf{f}, \mathbf{g})$; broad hallux with cutaneous complete syndactyly of interdigital spaces I-II and II-III on both feet; bilateral ped planus (h,i) and deep horizontal cutaneous skin crease at the base of the hallux (j).

Digital anomalies of the hands and feet (Figure 1e-j) included squared, broad thumbs $(\mathrm{e}, \mathrm{f})$; joint laxity with dorsiflexion of the distal phalanges $(\mathrm{f}, \mathrm{g})$; post-operative scar after surgical correction of preaxial polydactyly and broad hallux with cutaneous complete syndactyly of interdigital spaces I-II and II-III on both feet; bilateral pes planus (h,i); and deep horizontal skin cutaneous crease at the base of the hallux (j).

Additional anomalies were: congenital stridor (almost disappeared at the age of 3 years), small umbilical hernia, postoperative scar after surgical intervention for right cryptorchidism (at age 16 month), and a retractile left testicle.

Severe cognitive and motor delays were observed: head control was achieved at 6-7 months, sitting at 2 years, independent walking has not yet been achieved, and speech is limited to pronouncing a few syllables. The Mental Scale (Bayley II) score at 3 years of age was equivalent to 8 months.

Growth was assessed based on the Fenton Growth chart for preterm infants [20] and the Longitudinal Child Growth Standards of the Central Statistics Office of Hungary, by Joubert, Darvay and Ágfalvi, 2006 [21].

Morphological features are described according to the Human Malformation Terminology [22-25].

\subsection{Neuroimaging}

The cranial ultrasound at birth was not informative and the cranial MRI at 1 year and at 3 years showed hypoplasia of the corpus callosum, stenosis of the cerebral aqueduct, and mild supratentorial ventriculomegaly.

\subsection{Conventional and Molecular Cytogenetic Investigations}

The result of the karyotype and the aCGH analysis are described in Table 1. 
Table 1. Results of the cytogenetic- and the molecular cytogenetic investigations.

\begin{tabular}{|c|c|c|c|}
\hline & Results & $\begin{array}{l}\text { Size of the Deleted } \\
\text { Segment }(\mathrm{Mb})\end{array}$ & OMIM Genes \\
\hline Karyotype & 46,XY, del (7)(p13-p15) & & \\
\hline aCGH & $\begin{array}{c}\operatorname{arr}[\mathrm{hg} 38] 7 \mathrm{p} 14.2-\mathrm{p} 11.2 \\
(35830920-54201451) \times 1\end{array}$ & 18.04 & $\begin{array}{c}\text { ANLN, NME8, POU6F2, MPLKIP, GLI3, BLVRA, } \\
\text { GCK, NPC1L1, OGDH, CCM2, ADCY1, IKZF1, DDC, } \\
\text { PGAM2, CDK13, AEBP1, CAMK2B, SFRP4, PKD1L1, } \\
\text { VPS41, SUGCT, RALA }\end{array}$ \\
\hline $\mathrm{LOH}$ & - & 18.37 & $\begin{array}{l}\text { ANLN, NME8, POU6F2, MPLKIP, GLI3, BLVRA, } \\
\text { PGAM2, GCK, NPC1L1, OGDH, CCM2, ADCY1, } \\
\text { IKZF1, DDC, CDK13, AEBP1, CAMK2B, SFRP4, } \\
\text { PKD1L1, VPS41, SUGCT, RALA, SEPTIN7 }\end{array}$ \\
\hline
\end{tabular}

aCGH: comparative genomic hibridisation; a: array; arr: array; hg38: human genome version 38; LOH: loss of heterozygosity; Mb: megabase.

The clinical diagnosis of GCPS was made immediately after birth based on the characteristic phenotype suggestive of the syndrome.

Therapeutic interventions were focusing on correcting the digital anomalies to improve the patient's grasping manipulation and walking skills, as well as to improve cognitive functions by introducing continuous cognitive and kinetic stimulation.

The clinical course during the 6-year follow-up suggested a stationary condition regarding somatic development, which at the age of 6 years converged to normal, with weight being $22 \mathrm{~kg}$ (50-75th percentile), height $116 \mathrm{~cm}$ (50th percentile), and head circumference $53 \mathrm{~cm}$ (90-95th percentile). Regarding the psychomotor development, there was a mild improvement: at the age of 6 years, he is more active, his ability to cooperate gradually improves and his speech comprehension develops in terms of simple, often repetitive stimulances; vocalization is more monosyllabic; he enjoys listening to rhymes and music; the Mental Scale (Bayley II) score equal to that of a 15 month-old toddler; his right hand is more skillful, he inserts a few geometric elements, shows some of his body parts, climbs, kneels, clings, sometimes gets up, and steps with support by one hand.

\section{Discussion}

The diagnosis of GCPS was suggested immediately after birth based on the characteristic clinical signs of the syndrome and was confirmed by classical and molecular karyotyping.

The G-banded karyotype was 46,XY,del(7)(p13p15).

Molecular karyotype analysis (array-CGH) revealed an $18.37 \mathrm{Mb}$ interstitial deletion on the short arm of chromosome 7. Deletion breakpoints are located between p14.2 and p11.2 bands (35830920-54201451). The OMIM genes located in the deleted region are described in Table 1. The analysis of haploinsufficiency described a difference of $330 \mathrm{~kb}$, which is due to the different localization of the CNV and SNP probes.

Of the 205 genes included in the deleted segment, 22 were phenotype associated OMIM genes. Nine genes: GLI3 (Gli-Kruppel Family Member 3; OMIM\# 16540), ANLN (ActinBinding Protein Anillin; OMIM\# 616027), POU6F2 (Pou Domain, Class 6, Transcription2; OMIM\# 609062), GCK (Glucokinase; OMIM\#138079), CCM2 (Scaffold Protein; OMIM\# 607929), IKZF1 (Ikaros Family Zinc Finger 1; OMIM\# 603023), CDK13 (Cyclin-Dependent Kinase 13; OMIM\# 603309), CAMK2B (Calcium/Calmodulin-Dependent Protein Kinase Ii- $\beta$; OMIM\# 607707), and RALA (Ras-Like Protooncogene A; OMIM\# 179550) are known to be responsible for autosomal dominant mendelian disorders, of which GLI3 is the gene causing GCPS. Loss of function mutations of GLI3 determine the classic phenotype with craniofacial dysmorphism (macrocephaly, hypertelorism) and polysyndactyly; while gain of function mutations determine the Pallister-Hall syndrome (MIM\# 146510) $[3,8,10,13]$.

Mutations of the ANLN gene have been linked to functional or structural renal anomalies; those of the POU6F2 gene are associated with susceptibility to Wilms tumor (MIM\# 601583); mutations of the GCK gene cause MODY II diabetes; pathogenic variants of the CCM2 gene cause cavernous cerebral malformation; and those of the IKZF1 gene result in 
immunodefficiency, providing a reason for close follow-up and screening for comorbidities in our patient.

Five years after the diagnosis, we have reevaluated our case; we updated the OMIM genes involved in the deleted segment and we found three recently phenotype-associated, autosomal dominant OMIM genes: $C D K 13, C A M K 2 B$, and RALA. Only the RALA gene has been mentioned in four cases before (Jennifer J Johnston et al.) [6,7], but at that time (2003 and 2007) it had no known associated phenotype.

The $C D K 13$ and $C A M K 2 B$ genes have been recently annotated OMIM genes, related to syndromic neurodevelopmental disorders (congenital heart defects, dysmorphic facial features, intellectual developmental disorder associated to MIM\# 617360, mental retardation, and autosomal dominant 54 associated to MIM\# 617799) [26-33].

CDK13 codes for a member of the cyclin-dependent serine/threonine protein kinase (STK) family, which phosphorylate targets, such as RNA polymerase II-involved in extracellular and growth signaling [33]. The majority of mutations in CDK13 are missense mutations, occurring within the protein kinase domain leading to significant loss of catalytic activity. Hamilton et al. (2018) postulated their dominant-negative effect [26]. Genotype-phenotype studies suggested a trend toward milder phenotypes in patients with mutations predicted to cause haploinsufficiency of CDK13 [30].

The $C A M K 2 B$ gene encodes a subunit of calcium/calmodulin-dependent protein kinase II (CaM kinase II, CAMK2), a multifunctional serine/threonine kinase that has critical roles in the induction of hippocampal long-term potentiation and, as such, in synaptic plasticity, learning, and memory. Both loss-of-function and splice variants have been extensively studied and functionally characterized by Küry et al. in 2017 [31].

The RALA gene encodes a low molecular mass ras-like GTP-binding protein that shares about $50 \%$ similarity with other ras proteins. In neuronal culture systems, RALA has been implicated in the development, plasticity, polarization, migration, branching, and spine growth of neurons, as well as the renewal of synaptic vesicles and trafficking of NMDA, AMPA, and dopamine receptors to the postsynaptic membrane. Loss of function for RALA causes a severe neural tube defect; de novo missense variation disrupting the GTP/GDPbinding functions of RALA lead to developmental delay, intellectual disability, and related phenotypes (Hiatt-Neu-Cooper neurodevelopmental syndrome, MIM\# 619311) [34].

The deletion of these genes could have influenced the phenotype of our patient, especially the intellectual status, but their impact is indistinguishable from the GCPS-CGS phenotype. The macrosomia, hypertelorism, prominent metopic suture without confirmed craniosynostosis, anomaly of the corpus callosum, and polysyndactyly can be attributed to Greig cephalopolysyndactyly syndrome and haploinsufficiency of GLI3. Intellectual deficiency is rare in loss-of-function mutations of GLI3 associated with GCPS syndrome, but is frequently described and correlates with the size of deletion of GCPS-CGS [31].

Since the identification of $C D K 13, C A M K 2 B$ and $R A L A$ as syndromic, intellectual disability genes, we assume that the involvement of $C D K 13, C A M K 2 B$ and $R A L A$ genes in the deletion of our patient explains the presence and the severity of the intellectual disability. Callosal anomalies have also been reported in the $C A M K 2 B$-related intellectual disability [31].

To our knowledge, chromosomal deletion encompassing the genes $C D K 13, C A M K 2 B$ or RALA as a mechanism for intellectual disability related neurodevelopment delay disorders, have not been described so far.

Twelve further genes in the deleted segment: NME8 (NME/NM23 Family; OMIM\# 607421), MPLKIP (M-Phase-Specific Plk1-Interacting Protein; OMIM\# 609188), BLVRA (Biliverdin Reductase A; OMIM\# 109750), PGAM2 (Phosphoglycerate Mutase 2; OMIM\# 612931), OGDH (Oxoglutarate Dehydrogenase; OMIM\# 613022), ADCY1 (Adenylate Cyclase 1; OMIM\# 103072), DDC (Dopa Decarboxylase; OMIM\# 107930), AEBP1 (Ae-Binding Protein 1; OMIM\# 602981), SFRP4 (Secreted Frizzled-Related Protein 4; OMIM\# 606570), PKD1L1 (Polycystin 1-Like; OMIM\# 609721), VPS41 (Subunit Of Hops Complex; OMIM\# 605485), and SUGCT (Succinyl-Coa: Glutarate-Coa Transferase; OMIM\# 609187) are re- 
lated to recessive conditions, and the deletion of a single allele will not manifest as a disease unless the second allele has a mutation. The clinical signs of our patient cannot be correlated with the effects of these genes. Regarding the DDC gene, this would require further investigation (sequencing) given the risk of acute lymphoblastic leukemia (MIM\# 613067) [14,35].

The NPC1L1 (NPC-Like Intracellular Cholesterol Transporter 1; OMIM\# 608010) gene is responsible for the intestinal absorption of cholesterol, it is the molecular target for the drug ezetimibe, and variants in this gene affect response to this drug. The inheritance of the trait is not known, but monitoring cholesterol profile is relatively easy.

We only assume that the patient's deletion is de novo because, although the parents do not show clinical signs of the disease, it would have been necessary to perform q-PCR or microarray for them to exclude the inheritance of the deleted segment and high-resolution karyotype or FISH test to detect balanced chromosomal rearrangements. Genetic testing was declined by both parents, they are not willing to have further children.

A review of the literature of the patients with Greig cephalopolysyndactyly contiguous gene syndrome caused by a structural chromosomal anomaly (deletion) with a size greater than $1 \mathrm{Mb}$ is summarized in Table $2[3,4,6,7,11,13,16-19]$.

Table 2. Review of literature of the patients with GCP-CGS due to a chromosomal deletion encompassing GLI3 (>1 Mb).

\begin{tabular}{|c|c|c|c|}
\hline References & $\begin{array}{l}\text { Chromosomal } \\
\text { Localisation }\end{array}$ & $\begin{array}{l}\text { Size of the Deleted Segment } \\
(\mathbf{M b})\end{array}$ & Array Coordinates \\
\hline Present case & 7p14.2-p11.2 & 18.37 & arr[hg38](35830920_54201451)del \\
\hline Niida Y. et al [3] (2015) & 7p14.1-p12.3 & 6.2 & arr[hg19](41076615_47282889)del \\
\hline \multirow{2}{*}{ Demurger F. et al. [13] (2015) } & \multirow{2}{*}{ 7p13-p15 } & 7 & $\operatorname{arr}[$ hg19](38521704_45810267)del \\
\hline & & 9 & $\begin{array}{l}\operatorname{arr}[\text { hg19](35674000_37280000) } \\
\quad \text { _(46116000_46598000)del }\end{array}$ \\
\hline \multirow{3}{*}{ Jane A Hurst et al [11] (2011) } & \multirow{2}{*}{ 7p13-p14.1 } & 6.0 & arr[hg18](39013006_39213707)del \\
\hline & & 6.8 & arr[hg18](39130081_45492392)del \\
\hline & 7p12.3-p14.1 & 8.3 & $\begin{array}{c}\operatorname{arr}[\text { hg18](40845981_40855164) } \\
\quad \text { _(49136714_49160830)del }\end{array}$ \\
\hline Solveig Schulz et al. [4] (2008) & 7p13-7p14 & 14 & NA \\
\hline \multirow{2}{*}{ Debeer Philippe et al. [16] (2007) } & $7 \mathrm{p} 14.3$ & \multirow{2}{*}{ NA } & \multirow{2}{*}{ NA } \\
\hline & $7 \mathrm{p} 14.3$ & & \\
\hline \multirow{9}{*}{$\begin{array}{l}\text { Jennifer J Johnston et al. [6,7] } \\
\qquad(2003,2007)\end{array}$} & 7p14.1 & 1.8 & \multirow{9}{*}{ NA } \\
\hline & 7p14.1-7p13 & 3.2 & \\
\hline & $7 \mathrm{p} 14.1$ & 4.1 & \\
\hline & 7p14.1-7p13 & 5.2 & \\
\hline & 7p14.1-7p13 & 5.9 & \\
\hline & 7p14.2-7p14.1 & 6.3 & \\
\hline & 7p14.1-7p12.3 & 8.4 & \\
\hline & 7p14.2-7p13 & 9.8 & \\
\hline & 7p14.2-7p13 & 10.3 & \\
\hline \multirow{5}{*}{$\begin{array}{l}\text { Kroisel PM et al [12] } \\
\text { Schwarbraun T. et al. [18] } \\
\text { (2001, resp. 2005) }\end{array}$} & $7 \mathrm{p} 13$ & \multirow{5}{*}{$4.5-15$} & \multirow{5}{*}{ NA } \\
\hline & 7p12.3-p13 & & \\
\hline & 7p12.3-p13 & & \\
\hline & 7p12.3-p14.2 & & \\
\hline & 7p11.2-p13 & & \\
\hline Williams PG et al. [17] (1997) & 7p13-p15.1 & NA & NA \\
\hline Zneimer SM et al. [19] (2000) & $\begin{array}{c}\text { 45,XY,der(22;7) } \\
\text { (p13;p22.3)del } \\
\text { (7)-(p11.2-p15.1) }\end{array}$ & NA & NA \\
\hline
\end{tabular}


The genotype-phenotype correlation regarding the neurodevelopment in Greig cephalopolysyndactyly contiguous gene syndrome in our case and a further six cases (with available genomic coordinates) from the literature is presented in Table 3.

Table 3. Genotype-phenotype correlation.

\begin{tabular}{|c|c|c|c|c|}
\hline References & Patients's Age & $\begin{array}{l}\text { Size of the Deleted } \\
\text { Segment }(\mathrm{Mb})\end{array}$ & $\begin{array}{c}\text { Phenotype Associated } \\
\text { OMIM Genes }\end{array}$ & Neurodevelopment \\
\hline Present case * & $\begin{array}{c}3 \text { years } \\
\text { followed to age } 6\end{array}$ & 18.37 & $\begin{array}{c}\text { ANLN, NME8, POU6F2, MPLKIP, } \\
\text { GLI3, BLVRA, GCK, NPC1L1, OGDH, } \\
\text { CCM2, ADCY1, IKZF1, DDC, } \\
\text { PGAM2, CDK13, AEBP1, CAMK2B, } \\
\text { SFRP4, PKD1L1, VPS41, } \\
\text { SUGCT, RALA }\end{array}$ & $\begin{array}{l}\text { Severe intellectual disability, speech } \\
\text { and developmental delay }\end{array}$ \\
\hline $\begin{array}{l}\text { Niida Y. et al. * [3] } \\
\text { (2015) }\end{array}$ & 2 years & 6.2 & $\begin{array}{c}\text { GLI3, GCK, CCM2, AEBP1, CAMK2B, } \\
\text { PGAM2, BLVRA, ADCY1, } \\
\text { NPC1L1, OGDH }\end{array}$ & Developmental delay \\
\hline \multirow{2}{*}{ Demurger F. et al.* [13] (2015) } & NA & 7 & $\begin{array}{c}\text { GLI3, AEBP1, MPLKIP, GCK, CCM2, } \\
\text { CDK13, CAMK2B, VPS41, BLVRA, } \\
\text { PGAM2, ADCY1, SUGCT, POU6F2, } \\
\text { NPC1L1, RALA, OGDH }\end{array}$ & Developmental delay \\
\hline & NA & 9 & $\begin{array}{c}\text { GLI3, GCK, CDK13, MPLKIP AEBP1, } \\
\text { CCM2, CAMK2B, SFRP4, VPS41, } \\
\text { PGAM2, BLVRA, NME8, SUGCT, } \\
\text { ADCY1, NPC1L1, POU6F2, ANLN, } \\
\text { RALA, OGDH }\end{array}$ & Developmental delay \\
\hline \multirow{3}{*}{$\begin{array}{l}\text { Jane A Hurst et al.* [11] } \\
\text { (2011) }\end{array}$} & 2 years & 6.0 & $\begin{array}{c}\text { GLI3, GCK, CCM2, CDK13, MPLKIP, } \\
\text { AEBP1, CAMK2B, BLVRA, PGAM2, } \\
\text { SUGCT, RALA, POU6F2, } \\
\text { NPC1L1, OGDH }\end{array}$ & Developmental delay \\
\hline & 5 years & 6.8 & $\begin{array}{c}\text { GLI3, GCK, CCM2, CDK13, MPLKIP, } \\
\text { AEBP1, CAMK2B, BLVRA, PGAM2, } \\
\text { SUGCT, RALA, NPC1L1, } \\
\text { POU6F2, OGDH }\end{array}$ & $\begin{array}{l}\text { Severe intellectual disability, } \\
\text { speech and developmental delay }\end{array}$ \\
\hline & 15 years & 8.3 & $\begin{array}{c}\text { GLI3, GCK, CCM2, AEBP1, CAMK2B, } \\
\text { PKD1L1, BLVRA, PGAM2, SUGCT, } \\
\text { ADCY1, NPC1L1, OGDH }\end{array}$ & $\begin{array}{l}\text { Severe intellectual disability, speech } \\
\text { and delayed development }\end{array}$ \\
\hline
\end{tabular}

*: updated cases based on the available array coordinates; Neurodevelopment disorders related genes: $C D K 13, C A M K 2 B, R A L A$.

The haploinsufficiency of the $C D K 13, C A M K 2 B$ and $R A L A$ genes could influence the patients' neurodevelopment in five cases and the $C A M K 2 B$ gene in two cases.

\section{Conclusions}

The case presented here, with an $18 \mathrm{Mb}$ deleted chromosomal segment, is the largest deletion described in the related literature so far.

By describing the multitude of symptoms in our patient related to this large spanning deletion, encompassing several other genes than GLI3 responsible for intellectual disability, and by comparing our patient's features with literature data, we aimed to broaden the phenotypic and genotypic spectrum of GPS-CGS and find out about the possible comorbidities and prognosis. Sequence analysis would be useful to determine whether the variants on the other allele could contribute to the phenotype, therefore a whole exome sequencing has yet to be performed.

Author Contributions: Conceptualization, K.K., M.B.; investigation, K.K., A.U., I.S., M.I., S.Ş.Ş. and A.P.; resources, C.D.P., A.U., Z.S., I.S., M.I., S.Ş.Ş., A.P. and A.J.; writing—original draft preparation, K.K., M.B., C.M.J. and A.J.; writing-review and editing, K.K., M.B., I.S., K.S., C.N.S. and A.S.; visualization, M.B., A.S. and C.N.S.; supervision, M.B., K.S. and A.U.; validation, K.S. All authors have read and agreed to the published version of the manuscript.

Funding: This paper received financial support through the project "SmartDoct-High quality programs for doctoral students and postdoctoral researchers of the University of Oradea to increase the relevance of research and innovation in the context of regional economy", ID/Project code: 123008, co-financed by the European Social Fund through the Human Capital Operational Program 2014-2020. 
Institutional Review Board Statement: The study was conducted according to the guidelines of the Declaration of Helsinki, and approved by the Ethics Committee of Municipal Clinical Hospital “Dr. Gavril Curteanu" Oradea, Romania (protocol code 32811/15.09.2021).

Informed Consent Statement: Written informed consent has been obtained from the parents of the patient to publish this paper.

Data Availability Statement: Not applicable.

Acknowledgments: The authors would like to thank the family who participated in the study.

Conflicts of Interest: The authors declare no conflict of interest.

\section{References}

1. Biesecker, L.G.; Johnston, J.J. Greig Cephalopolysyndactyly Syndrome; Adam, M.P., Ardinger, H.H., Pagon, R.A., Eds.; University of Washington: Seattle, WA, USA, 1993; pp. 1993-2020.

2. Biesecker, L.G. The Greig cephalopolysyndactyly syndrome. Orphanet. J. Rare Dis. 2008, 3, 10. [CrossRef]

3. Niida Yo Ozaki, M.; Takase, E.; Yokoyama, T.; Yamada, S. A Girl with Greig Cephalopolysyndactyly Contiguous Gene Deletion Syndrome: The Importance and Usefulness of DNA Microarray Analysis. Genetics 2015, S7, 4. [CrossRef]

4. Schulz, S.; Volleth, M.; Muschke, P.; Wieland, I.; Wieacker, P. Greig cephalopolysyndactyly (GCPS) contiguous gene syndrome in a boy with a $14 \mathrm{Mb}$ deletion in region 7p13-14 caused by a paternal balanced insertion (5; 7). Appl. Clin. Genet. 2008, 1, 19-22. [CrossRef] [PubMed]

5. McKusick, V.A. Mendelian Inheritance in Man. Available online: http:/ / www.ncbi.nlm.nih.gov/omim (accessed on 25 May 2021).

6. Johnston, J.J.; Olivos-Glander, I.; Turner, J.; Aleck, K.; Bird, L.M.; Mehta, L.; Schimke, R.N.; Heilstedt, H.; Spence, J.E.; Blancato, J.; et al. Clinical and molecular delineation of the Greig cephalopolysyndactyly contiguous gene deletion syndrome and its distinction from acrocallosal syndrome. Am. J. Med. Genet. A 2003, 123A, 236-242. [CrossRef]

7. Johnston, J.J.; Walker, R.L.; Davis, S.; Facio, F.; Turner, J.T.; Bick, D.P.; Daentl, D.L.; Ellison, J.W.; Meltzer, P.S.; Biesecker, L.G. Zoom-in comparative genomic hybridisation arrays for the characterisation of variable breakpoint contiguous gene syndromes. $J$. Med. Genet. 2007, 44, e59. [CrossRef]

8. Johnston, J.J.; Olivos-Glander, I.; Killoran, C.; Elson, E.; Turner, J.T.; Peters, K.F.; Abbott, M.H.; Aughton, D.J.; Aylsworth, A.S.; Bamshad, M.J.; et al. Molecular and Clinical Analyses of Greig Cephalopolysyndactyly and Pallister-Hall Syndromes: Robust Phenotype Prediction from the Type and Position of GLI3 Mutations. Am. J. Hum. Genet. 2005, 76, 609-622. [CrossRef] [PubMed]

9. Pettigrew, A.L.; Greenberg, F.; Caskey, C.T.; Ledbetter, D.H. Greig syndrome associated with an interstitial deletion of 7p: Confirmation of the localization of Greig syndrome to 7p13. Hum. Genet. 1991, 87, 452-456. [CrossRef] [PubMed]

10. Siracusano, M.; Riccioni, A.; Baratta, A.; Baldi, M.; Curatolo, P.; Mazzone, L. Autistic symptoms in Greig cephalopolysyndactyly syndrome: A family case report. J. Med. Case Rep. 2019, 13, 100. [CrossRef] [PubMed]

11. Hurst, J.A.; Jenkins, D.; Vasudevan, P.C.; Kirchhoff, M.; Skovby, F.; Rieubland, C.; Gallati, S.; Rittinger, O.; Kroisel, P.M.; Johnson, D.; et al. Metopic and sagittal synostosis in Greig cephalopolysyndactyly syndrome: Five cases with intragenic mutations or complete deletions of GLI3. Eur. J. Hum. Genet. 2011, 19, 757-762. [CrossRef]

12. Kroisel, P.M.; Petek, E.; Wagner, K. Phenotype of five patients with Greig syndrome and microdeletion of 7p13. Am. J. Med. Genet. 2001, 102, 243-249. [CrossRef]

13. Démurger, F.; Ichkou, A.; Mougou-Zerelli, S.; Le Merrer, M.; Goudefroye, G.; Delezoide, A.-L.; Quélin, C.; Manouvrier, S.; Baujat, G.; Fradin, M.; et al. New insights into genotype-phenotype correlation for GLI3 mutations. Eur. J. Hum. Genet. 2014, $23,92-102$. [CrossRef] [PubMed]

14. Mendoza-Londono, R.; Kashork, C.D.; Shaffer, L.G.; Krance, R.; Plon, S.E. Acute lymphoblastic leukemia in a patient with Greig cephalopolysyndactyly and interstitial deletion of chromosome $7 \operatorname{del}(7)(p 11.2$ p14) involving the GLI3 and ZNFN1A1 genes. Genes Chromosomes Cancer 2005, 42, 82-86. [CrossRef] [PubMed]

15. Chotai, K.A.; Brueton, L.A.; van Herwerden, L.; Garrett, C.; Hinkel, G.K.; Schinzel, A.; Mueller, R.F.; Speleman, F.; Winter, R.M. Six cases of 7p deletion: Clinical, cytogenetic, and molecular studies. Am. J. Med. Genet. 1994, 51, 270-276. [CrossRef]

16. Debeer, P.; Devriendt, K.; De Smet, L.; Deravel, T.; Gonzalez-Meneses, A.; Grzeschik, K.-H.; Fryns, J.-P. The spectrum of hand and foot malformations in patients with Greig cephalopolysyndactyly. J. Child. Orthop. 2007, 1, 143-150. [CrossRef] [PubMed]

17. Williams, P.G.; Hersh, J.H.; Yen, F.F.; Barch, M.J.; Kleinert, H.E.; Kunz, J.; Kalff-Suske, M. Greig cephalopolysyndactyly syndrome: Altered phenotype of a microdeletion syndrome due to the presence of a cytogenetic abnormality. Clin. Genet. 1997, 52, 436-441. [CrossRef] [PubMed]

18. Schwarzbraun, T.; Windpassinger, C.; Ofner, L.; Vincent, J.B.; Cheung, J.; Scherer, S.W.; Wagner, K.; Kroisel, P.M.; Petek, E. Genomic analysis of five chromosome 7p deletion patients with Greig cephalopolysyndactyly syndrome (GCPS). Eur. J. Med. Genet. 2006, 49, 338-345. [CrossRef] [PubMed]

19. Zneimer, S.M.; Cotter, P.D.; Stewart, S.D. Telomere-telomere (end to end) fusion of chromosomes 7 and 22 with an interstitial deletion of chromosome 7p11.2 $\rightarrow$ p15.1: Phenotypic consequences and possible mechanisms. Clin Genet. 2000, 58, 129-133. [CrossRef] [PubMed] 
20. Fenton, T.R.; Kim, J.H. A systematic review and meta-analysis to revise the Fenton Growth chart for preterm infants. BMC Pediatr. 2013, 13, 59. [CrossRef]

21. Joubert, K.; Gy, G.; Darvay, S.; Ágfalvi, R. Results of the Hungarian Longitudinal Child Growth Study: From Birth to the Age of 18 Years (I). January 2010. Available online: https:/ / edit.elte.hu/xmlui/bitstream/handle/10831/10549/Kutjel83_honlapra.pdf? sequence $=1$ (accessed on 17 October 2021).

22. Allanson, J.E.; Cunniff, C.; Hoyme, H.E.; McGaughran, J.; Muenke, M.; Neri, G. Elements of morphology: Standard terminology for the head and face. Am. J. Med. Genet. A 2009, 149A, 6-28. [CrossRef]

23. Biesecker, L.G.; Aase, J.M.; Clericuzio, C.; Gurrieri, F.; Temple, I.K.; Toriello, H. Elements of morphology: Standard terminology for the hands and feet. Am. J. Med. Genet. A 2009, 149A, 93-127. [CrossRef]

24. Carey, J.C.; Cohen MMJr Curry, C.J.; Devriendt, K.; Holmes, L.B.; Verloes, A. Elements of morphology: Standard terminology for the lips, mouth, and oral region. Am. J. Med. Genet. A 2009, 149A, 77-92. [CrossRef]

25. Hennekam, R.C.; Biesecker, L.G.; Allanson, J.E.; Hall, J.G.; Opitz, J.M.; Temple, I.K.; Carey, J.C.; Elements of Morphology Consortium. Elements of morphology: General terms for congenital anomalies. Am. J. Med. Genet. A 2013, 161A, 2726-2733. [CrossRef]

26. Hamilton, M.J.; Suri, M. CDK13-related disorder. Adv. Genet. 2019, 3, 163-182. [CrossRef]

27. Bostwick, B. CDK13-Related Disorder; Adam, M.P., Ardinger, H.H., Pagon, R.A., Eds.; University of Washington: Seattle, WA, USA, 1993; Available online: https:/ / www-ncbi-nlm-nih-gov.ezproxy.u-pec.fr/books/NBK536784/ (accessed on 31 January 2019).

28. Sifrim, A.; Hitz, M.-P.; Wilsdon, A.; Breckpot, J.; Al Turki, S.H.; Thienpont, B.; McRae, J.; Fitzgerald, T.W.; Singh, T.; Swaminathan, G.J.; et al. Distinct genetic architectures for syndromic and nonsyndromic congenital heart defects identified by exome sequencing. Nat. Genet. 2016, 48, 1060-1065. [CrossRef]

29. Greifenberg, A.K.; Hönig, D.; Pilarova, K.; Düster, R.; Bartholomeeusen, K.; Bösken, C.A.; Anand, K.; Blazek, D.; Geyer, M. Structural and Functional Analysis of the Cdk13/Cyclin K Complex. Cell Rep. 2016, 14, 320-331. [CrossRef] [PubMed]

30. Hamilton, M.J.; Caswell, R.; Canham, N.; Cole, T.; Firth, H.V.; Foulds, N.; Heimdal, K.; Hobson, E.; Houge, G.; Joss, S.; et al. Heterozygous mutations affecting the protein kinase domain of CDK13 cause a syndromic form of developmental delay and intellectual disability. J. Med Genet. 2017, 55, 28-38. [CrossRef] [PubMed]

31. Küry, S.; Van Woerden, G.M.; Besnard, T.; Onori, M.P.; Latypova, X.; Towne, M.C.; Cho, M.T.; Prescott, T.E.; Ploeg, M.A.; Sanders, S.; et al. De Novo Mutations in Protein Kinase Genes CAMK2A and CAMK2B Cause Intellectual Disability. Am. J. Hum. Genet. 2017, 101, 768-788. [CrossRef] [PubMed]

32. Rizzi, S.; Spagnoli, C.; Salerno, G.G.; Frattini, D.; Caraffi, S.G.; Trimarchi, G.; Moratti, C.; Pascarella, R.; Garavelli, L.; Fusco, C. Severe intellectual disability, absence of language, epilepsy, microcephaly and progressive cerebellar atrophy related to the recurrent de novo variant $\mathrm{p}$ (P139L) of the CAMK2B gene: A case report and brief review. Am. J. Med. Genet. Part A 2020, 182, 2675-2679. [CrossRef]

33. Heiman, P.; Drewes, S.; Ghaloul-Gonzalez, L. A familial case of CAMK2B mutation with variable expressivity. SAGE Open Med. Case Rep. 2021, 9. [CrossRef]

34. Hiatt, S.M.; Neu, M.B.; Ramaker, R.C.; Hardigan, A.A.; Prokop, J.W.; Hancarova, M.; Prchalova, D.; Havlovicova, M.; Prchal, J.; Stranecky, V.; et al. De novo mutations in the GTP/GDP-binding region of RALA, a RAS-like small GTPase, cause intellectual disability and developmental delay. PLoS Genet. 2018, 14, e1007671. [CrossRef]

35. Sava, C.N.; Ritli, L.; Balmoş, A.B.; Iuhas, A.R.; Marian, P.; Motorca, M.A.; Lele, L.A.; Straciuc, O.; Zaha, D.C.; Jurcă, M.C.; et al. Unusual extramedullary relapses in a case of common B-cell acute lymphoblastic leukemia. Case Rep. Rev. Lit. 2019, 60, 249-254. 